\title{
Pamali, Bajo's Local Wisdom in the Conservation of Marine Resources
}

\author{
La Ode Ali Basri ${ }^{1}$, I Wayan Mudana ${ }^{2}$, Wa Ode Sitti Habsah ${ }^{3}$, Akhmad Marhadi ${ }^{3}$, La Tarifu ${ }^{4}$, Faika Burhan ${ }^{1}$, La Janu ${ }^{3}$ \\ ${ }^{1}$ Department of Historical Science, Faculty of Cultural Science, Universitas Halu Oleo Kendari \\ ${ }^{2}$ Department of Sociology, Faculty of Law and Social Sciences, Universitas Pendidikan Ganesa Singa Raja \\ ${ }^{3}$ Department of Antropology, Faculty of Cultural Science of Universitas Halu oleo Kendari \\ ${ }^{4}$ Department of Communication Science, faculty of Social and Political Science, Universitas Halu Oleo Kendari \\ Correspondent: La Ode Ali Basri, Department of Historical Science Faculty of Cultural Science of Universitas Halu \\ Oleo Kendari, Southeast Sulawesi, Indonesia. Tel: 081341797344. E-mail: basri.uho74@gmail.com
}

Received: August 26, 2017

doi:10.5539/ass.v13n12p63

\author{
Accepted: October 16, $2017 \quad$ Online Published: November 28, 2017 \\ URL: https://doi.org/10.5539/ass.v13n12p63
}

\begin{abstract}
The purpose of this study is to examine and analyze the tradition of pamali (taboo/tobo) as one of local wisdom of Bajo tribe in the conservation of marine resources. This research was conducted in Bungin Permai Village, South Konawe District, Southeast Sulawesi. Data collection techniques were conducted through in-depth interviews, involved observations, document studies and focused discussions. Data analysis is done through data reduction, data presentation and conclusion. The results show that pamali or abstinence is one of local wisdom of Bajo tribe in the conservation of marine resources born from their life experiences in interacting with the sea, with the same (Bajo tribe) and bagai (people outside Bajo tribe), and their relationship with Mbo (God) the ruler of the sea. Pamali arranges matters relating to the survival of ecosystems and marine biota, such as pamali of catching fish or collecting seafood around the coral reefs, in pasi and pamali of catching marine animals seen as the embodiment of Mbo. Pamali also deals with the safety of individuals and Bajo society generally, because the Bajo tribe believes in pamali as karma law, if it is violated will befall the person who violates it or its family and its offspring anytime and anywhere. The understanding of pamali gave birth to the concept of self-conscious behavior in the management of marine resources called empe diri (empat diri) that is Self-Awareness, Self-Endurance, Self-Conception and Self-Confidence.
\end{abstract}

Keywords: local wisdom, pamali, conservation of marine resources, and Bajo tribe.

\section{Preliminary}

The Bajo tribe has different names, namely in West Indonesia as the Sea people or Sea tribe. In the eastern part of Indonesia, these groups are called Bajo, Bajau, or Sama-Bajo, while in some Asian countries such as Malaysia, the Philippines calls Bajau. Kazufumi and Lapian (1997) refer to Bajo as Sea Tribe with high mobility rate, living in coastal areas or above sea waters with livelihood activities as traditional fishermen. Although the Bajo tribe has different names, but from the aspect of cultural characteristics, this ethnic is a group of coastal communities or maritime culture. Its maritime characteristics can be identified primarily in their model of environmental management of settlements over marine waters, livelihoods as traditional fishermen, knowledge systems, technology, economic systems and social organization of the Bajo tribe centered on the utilization of marine and coastal resources.

The characteristics of Bajo tribe, clearly implicit in the local wisdom that embodied in their cosmology that "Mbo kita ne lino baka isi-isina, kita neje manusiana mamikker iyya batingga kole'ta mangelola iyya" (God has given this world to all its contents to humans, so we have to think and manage it well and wisely). The Bajo tribe interprets the sea as life. The sea is a garden as well as their yard. They believe that their ancestors came from the sea, live in the sea, and as Mbombongana lao (ruler of the sea) who can provide sustenance, goodness, health, and protect people from disaster. In the view of the Bajo tribe, this philosophy implies that the Bajo People will never experience hunger or poverty because the seas are infinite with all the potential and wealth of resources in it is the source of life.

The study of Bajo people and their local wisdom has been done by several researchers, such as Saat (2003) stated that the Bajo tribe in Malaysia, the Philippines and Indonesia is relatively the same that is always viewed as a tribe or society that builds its civilization base on the sea or coastal, with a low degree of civilization when compared to other tribes. Saat and Mansur (2016) also conducted a study of issues in diaspora of Sama Dilaut and its consequences in Sabah Malaysia. The results show that although the Bajo or Sama-Bajau has adopted the culture of urban society, it is still categorized as the Sama Dilaut group. Meanwhile, Ismail et al (2015) study shows that Bajo people are maritime communities living in coastal areas.

In the Indonesian context, the study of Bajo People was done by Saidi (2001) that the Bajo people interpret the sea stretching unlimitedly on the surface of the earth, as a space to engage in activity, as well as space to perform the process of inheritance of values to the next generation. The findings are reinforced by Bahtiar and Basri (2011) that the 
Bajo people view the ocean as a source of life, which plays an important role in their economy.

Another study was also conducted by Basri (2010) which shows that the Bajo People have a potent set of local cultures as a catalyst for the empowerment of the Bajo community, and has a set of traditional knowledge in eco-friendly fishing such as rompoh, pempeso and bhala. Meanwhile, Suryanegara et al (2015) stated that the Bajo people have local wisdom in managing marine resources held firm by the people. They have a rule in terms of fishing, one of which they always choose a fish that is mature. Similarly to the findings of Baskara and Astuti (2011), that Bajo People are known as sea tribes because they live in the sea, and the sea is their primary source of life. According to Bajo People, the sea should not be damaged because it is their brother, so in the view of the Bajo that the sea will take care of them.

Meanwhile, Indrawasih and Antariksa (2003) study results show that Bajo people have local wisdom to preserve their environment, such as corals, mangroves and other marine resources. The wood they grab from the branches that have dried, because they realize mangrove is the main of resources. They will soon stop exploiting resources in certain areas and move to other places if they feel the resources are getting wild and diminishing, thus allowing resources to multiply. In line with these findings, Bahtiar (2012) states that the Bajo people have local wisdom in the conservation of marine resources called ongko, namely the arrangement of place or location of fishing based on the habit of a person or group of people. With this system the Bajo people not mutually seize the catch location. While Artanto (2017) states that the Bajo people have local wisdom in the preservation of coastal and sea called bapongka, which is a group of sea fishing activities for several weeks or monthly by using a traditional boat called leppa or sopek. According to Artanto (2017) bapongka is one model of conserving the marine environment in a sustainable manner. All the results clarify that the Bajo people have a set of local wisdom utilized in conserving marine resources, one of which is the Bajo people of Pamali who settled in Bungin Village of South Konawe, Southeast Sulawesi.

\section{Research Methods}

This research was conducted in Bungin Village of South Konawe Regency, Southeast Sulawesi, Indonesia which was held for three months. The main informants in this study were traditional elders, youth leaders, and ordinary citizens determined purposively. Data collection techniques were conducted through: (1) observations involved in aspects of local wisdom of Bajo people related to marine and coastal resource management, (2) in-depth interviews to Bajo figures, religious leaders, traditional leaders, youth leaders and other Bajo people about ideas, experiences, knowledge of informants about various matters related to local wisdom, Bajo tribe's activities, and their relationship with the outside world, (3) conducting document studies, especially documents related to Bajo culture.

Data analysis was done descriptively-qualitatively, through four steps, namely (1) arranging the units of all data collected from the interview, observation, literature study and focus group discussion divided one by one, collected according to its class, then done data reduction in order to eliminate irrelevant data, create abstractions and arrange data units; (2) categorize data so that the process of categorization and data grouping can be better; (3) arranging relationships between categories, comparing one with other data, and interpreting the meaning of each relationship data; and (4) provide interpretation and relationships between categories of data that have been grouped so that can be found meaning and conclusion. In the research data collection activities, used several tools such as data cards and interview guides. The data cards are used for recording, categorizing, and classifying data, while interview guides are used as referrers during interviews. Another tool used is a photo camera or video camera to record observations and recorders to record the results of the interview.

\section{Result and Discussion}

The Bajo people pay attention seriously to the marine environment, because the ocean is the pulse of their economy. The sea is seen as a source of life and livelihood of Bajo people, who play a role in helping to improve their economic level. The sea as a place to earn a living is seen as a sacred place, so it should not be arbitrary. Therefore, Bajo people conserve marine resources through customary rules of pamali and environmental care actions such as planting mangroves in coastal areas. The Bajo ancestors appreciate it in the expression of philosophy "kadampaannu kampo maiga-iga, pugai allou mabunda ana'umputa ". (Love the marine environment for the future of our children and grandchildren). The expression is a reflection of the high sense of belonging Bajo people to the sea, so they always maintain and preserve the precious source of life.

In running the sea activities there are also some restrictions or pamali that must be considered and not be violated. Pamali is related to the survival of ecosystems and marine biota, and there is also related to the safety of individuals and Bajo society in general. The prohibiton relating to the survival of ecosystems and marine biota, such as not catching fish or taking other marine products on corals, in pasi (sandy ground in the sea in the form of delta) because these places are believed to be the residence of Mbo, God Ruler of the sea. Prohibition of catching marine animals that are considered to be the embodiment of Mbo, such as octopus fish, bawal fish, kulintang, kunyu boe (a kind of turtle), mermaid like dolphins and sharks. The existence of a ban on catching the sea animals, in addition to being regarded as sea-like incarnation animals, there are also marine animals such as bawal fish, which according to the Bajo people that the fish in the past have merit to save their ancestors when having an accident at sea. Therefore, the Bajo people regard the animal as a human friend.

Therefore, Bajo people in Bungin also develop equipment systems that pay attention to coral reef conservation, namely by making a pempeso fish traps or other marine animals made from woven bamboo or rattan. Pempeso is usually 
dissolved in the seabed near the reef or around the reef called the fish house as well as Mbo house. However, the Pempeso system does not damage the coral reef, because the Bajo people put it by considering the safety aspect of the pempeso when lifted from the seabed. In one part of the pempeso is usually stored stone or iron to facilitate sinking in the seabed. Pempeso is also tied with a long rope and moored in a boat or tree and then stored for a few hours or also left overnight and drawn the next day. In addition, the Bajo people also use rompoh (rumpon) made from bamboo and coconut leaves. The Bamboo is formed to resemble a raft, on the bottom and sides of rompoh hung coconut leaves, so the fish gathered in that place. The Bajo people put up a net around the rompoh. Besides rompoh, the Bajo people also use bhalla (traditional cage) to catch fish.

According to the traditional view of the Bajo people this arresting technique is seen as not disturbing the convenience of Mbo as the provider of sustenance and the sea guard. For that, the Bajo people always maintain the attitude and actions that can cause Mbo wrath to them. One of the implementation is that they are strongly believes with pamali. The Bajo people believe that they should not damage the pamali place or violated the pamali. If they do it, they will get punishment or curse from Mbo, a serious illness or death, drown in the sea, strangled, and so on.

In a story it is told that in Bungin village there was once a Bajo man who still gagga (strong and healthy) died at the time of ngarua (catching fish during the day) with nubba (by whipping water with a stick or paddle). When the man was beating water with a stick, he suddenly fell from his boat. According to the society, the young matai (died) killed by the spirits for violating pamali. He was too hard to hit the water with a stick and did not recognize the stench around the rock where he caught fish.

The Bajo people never investigate the cause of a person's death, especially when someone dies while catching a fish. For the Bajo people, it is clearly a sign of the spirit's actions and a warning to others. According to the Bajo people one's death is an act of Satan, but if Sama is not violated pamali will get protection from Mbo. For Bajo people is a real and absolute reality. The people who make mistakes or do not obey pamali will be punished, both in quick and long time. If the karma or punishment does not occur directly to the person concerned, then the karma or punishment will befall to the family, children, grandchildren or its derivatives. Therefore, the Bajo People must apply humanist in managing the marine resources that exist around them.

The doctrine to apply humanist to fellow creatures, poured in the form of pamali about the prohibition of killing pigs or deer who come down in the sea. In the Bajo People conception, Mbo has a good relationship with the landlord, so they must refrain from killing pigs, deer or other land animals that descend into the sea. Because according to them may be the animal is the embodiment of Mbo ma on land (landlord). This view, in line with the results of Zacot (2008) study indicating that the Bajo people not only have pamali in the sea but also have some taboos related to life on land. According to Zakot, the pamali is inherently influential with the life of the Bajo people as a whole.

The concept of pamali in Bajo society if analyzed scientifically is actually loaded with meaning. These places are places that can support the sustainability and balance of marine ecology and the future of mankind. Similarly, marine animals in traditional thought of Bajo people are Mbo's incarnation animals so become pamali, is a marine species protected by the state. Gaaras (coral reef) is one of the places which the Bajo belief that Mbo lives in that place, and every place in Mbo has many fish and other types of marine life, because Mbo is the owner. The Bajo people should not catch fish in this place and not destroy it, because it can get wrath from Mbo.

The Bajo's view of coral reef function or in Bajo society is called garas has a very close coherence with the study of marine science that coral reef is a marine resource that is very useful for the benefit of mankind. In coral reef marine science has the following functions (1) as coastal protection, as well as retaining the waves in order to avoid abrasion in the shore and reduce erosion; (2) coral reefs can reduce the impact of global warming; (3) to support the life of various types of living things that exist in the vicinity. Coral reefs provide shelter, feeding, and breeding for a variety of marine biota, as a gathering place for fish and marine organisms, because coral reefs own and store food needed by fish and other marine organisms; (4) as biodiversity; areas that have many coral reefs also have many marine organisms; (5) a lime deposition reservoir containing carbon; (6) coral reefs also function to reduce the carbon released into the atmosphere so as to reduce the impact of ozone damage and global warming; (7) as a tourist attraction, (https://alamendah.org/accessed on August 19, 2017).

Understanding and interpreting the functions of pamali in Bajo society, it can be said that Bajo tribe actually long before the discovery of conventional conservation ideas (modern), Bajo society have conservation ideas based on their local culture. Pamali culture is very adhered by the Bajo people is a form of high concern for the sustainability of the marine environment, especially the environment around the coral reef as a buffer underwater ecosystems. In addition, the habit of Bajo people to plant tongke (mangrove) is one form of mitigasi tactic, in the form of hurricanes or large waves. According to the Bajo people, if around their village there are mangroves, then the wind will not directly hit their house, but will first be blocked by mangrove trees, so that the wind power can be reduced. Thus they will be spared from the wind like tornado.

The Bajo local wisdom in marine conservation is strengthening the findings of Taena et al (2016) and Basri et al (2017). According to Taena et al (2016) states that local wisdom can be found in any community in the world, while Basri et al (2017) states that each community group has its own traditional culture and local wisdom that characterizes the uniqueness of the community. The Bajo local wisdom is embodied in a system of religious beliefs and emotional 
bonds in their transcendental relationship with Mbo Ma Dilao's power, conception and expression of life and the nature of life, purpose, orientation, knowledge and the framework of their interpretation of the sea world, cultured sea (Basri, et al, 2011).

Understanding and appreciation of Pamali gave birth to the concept of self-conscious behavior in the management of marine resources called self empe (empat-diri) namely, tahan diri (self-endurance), ngatonang diri (self-awareness), angga' diri (self-conception), and matappa diri (self-confidence). Self-endurance, contain meaning in seeking or trying not to be greedy, can not justify any means, furthermore to damage the marine environment. The sea must always be preserved and nurtured, as the primary source of life, for the future of their children and grandchildren. Bajo people believe that they are the chosen people who have been destined to inhabit and guard the sea. They regard themselves as descendants of the God of the sea, who are entitled to design and determine their own course of life at the sea. Therefore they can not be separated by the sea. The sea belongs to those who have been awarded by God to be managed by the Bajo people.

Self-awareness means that the source of sustenance is Mbo (God of the Sea), then in searching should not solely rely on the luck factor, but must be followed by a prayer to Mbo God of the sea ruler. Bajo people realize that their ability in trying is so limited that the final result is entirely back to Mbo. For that, all forms of pamali that might make Mbo wrath to them are always avoided. Even to attract the sympathetic of Mbo to always bless them in searching or working at sea, since the making and use of new boats and at every time go to the sea is always preceded by ceremonies and rituals, one of which is the ritual mangujuiyya leppa (boat blessing) and maduai loa (respect for the sea). According to the Bajo People, the wisdom of ceremony is to get bless from Mbo for a new boat. Thus, between the boat and sea can unite and many get sustenance, the boat is durable or not quickly damaged and protected from danger. For the boat owners will get a lot of seafood so that never suffer from lack of food or poverty.

Self-conception implies that the Bajo are the chosen people who have been destined by God to inhabit the sea. They are proud to call themselves as sea people and they group themselves into sama (the group of Bajo people) and bagai (foreigners or people outside Bajo). They believe that they are descendants of the God of the Sea, who are entitled to determine and design the direction of life at sea. Nothing can separate them with the sea except death. Bajo people have naturally united themselves with marine life in harmony with their natural resources and become part of the sea in all its aspects. The Bajo people recognize the sea as knowing themselves, love it, wrestle deep into it and blend with their true life. They feel the serenity and peace in the cradle of the waves of the sea.

Self-confidence means that in seeking or trying they believe in the abilities they possess. Individual ability and collective awareness are the capital that can build and develop their economies. Nothing bagai will pay attention to their lives, except the fellow Bajos. They must live out of their own efforts and their group. Individually, the average Bajo is a diligent worker tirelessly, so whatever they do is always completed, regardless of time. The Bajo people have personality that is able to utilize the potential of natural resources in the surrounding as a tool that can fulfill the needs of his life. The various crafts as a mirror how high knowledge and skills they have is one form of their creativity results. In collective life, the spirit of "kebajoan" seems so strong. They always work together to help each other to relieve the burden of life with the principles of situlu-tulu (helping each other), sikaada (mutual acceptance), and sippatappa (mutual trust). The above description shows that the Bajo community has a set of local wisdom stored in its social and cultural system (Basri, et al, 2017).

Observing the knowledge of Bajo people in the management of marine resources as described above then linked with the Bajo's traditional view that the ocean is an endless resources, it seems that their conception is not entirely wrong, not even at all. Because, the Bajo people have a set of rules that conceptualized pamali that they always obey. Indonesia has a coastline of approximately $100,000 \mathrm{~km}$, is the second longest beach line in the world after Canada with the world's most complete biodiversity (http://www.antaranews.com, accessed 19/9/2017), if managed wisely with using environmentally friendly technology as exemplified by the ancestors of the Bajo people, of course the marine resources will be preserved sustainability and will be functional for human life.

\section{Conclusion}

Pamali is a banned which is always upheld by the Bajo people in carrying out the sea activities because it is believed to be true, if violated will bring mudharat (badness) for those who do not heed it. In the life of Bajo, pamali serves as a controller for individuals and society collectively in order not to be bad behaviour, not to do acts that damage the environment, not to do acts that violate Mbo's command, not violate ethics norms. Pamali arranges matters relating to the survival of ecosystems and marine biota, such as pamali catching fish or harvesting seafood around the coral reefs, in pasi, and catching marine animals that are seen as the embodiment of Mbo. Pamali also deals with the safety of individuals and Bajo society in general, because the Bajo people believe in pamali as karma law, if it is violated its karma will happen to those who violate it or its family and offspring anytime and anywhere.

Understanding of pamali gave birth to the concept of self-conscious behavior in the management of marine resources called the empe diri (empat diri) that is Self-Awareness, Self-Defense, Self-Conception and Self-Confidence. Self-Awareness contains meaning of Bajo people realize that they have many weaknesses so that always rely on Mbo. Self-Defense means not to allow any strategy to use marine resources. Self-Conception means Bajo people are proud to be sea people, while Self-Confidence contains the meaning of Bajo People believe in the socio-cultural system, the 
original knowledge and skill system that they have as the main capital in navigating life at sea.

\section{References}

Alamendah. (2015 July 23). Manfaat Terumbu Karang Bagi Manusia dan Lingkungan. Retrieved August 19, 2017, from https://alamendah.org

Antranews. (2015 Maret 27). Garis Pantai Indonesia Terpanjang Kedua di Dunia. Retrieved August 19, 2017, from $\mathrm{http}: / / \mathrm{www}$. antaranews.com/berita/487732.

Artanto, Kristiani, Yohanes. (2017). Bapongka, Sistem Budaya Suku Bajo dalam Menjaga Kelestarian Sumber Daya Pesisir. Sabda, 12(1), 52-69.

Bahtiar. (2012). The Local Genius Aplied by the Bajo People to Managing Sea Sources. Mudra, 27(2), 178-185.

Bahtiar, dan Basri, Ali, Ode, La. (2011). Philosophical View And Rarambangah System: A Local Genius Of The Bajau People Living at Bungin Permai Village, Southeast Sulawesi. Mudra, 26(3), 246-252.

Baskara, Benny, dan Astuti, Oce. (2011). The "Pamali" of Wakatobi Bajo and Its Role for Marine Conservation. Journal of Indonesia Coral Reefs, 1(2), 85-90.

Basri, Ali, Ode, La. (2010). Pemanfaatan Kearifan Lokal Sebagai Modal Sosial Budaya Dalam Pemberdayaan Masyarakat Pesisir Etnik Bajo. (Disertasi Doktor, tidak dipublikasi). Universitas Udayana, Bali, Denpasar.

Basri, Ali, Ode, La, Aso, La, Momo, H., A, Mudana, Wayan, I, Taena, La, Salniwati, Janu, La, \& Aswati. (2017). The Valuas of Multicultural Education in Munanese Traditional Culture. Asian Culture and History, 9(1), 33-39. https://doi.org/10.5539/ach.v9nlp33

Basri, Ali, Ode, La, Mudana, W. I, Rahaman, A. (2017). The Negative Stigma Against the Bajo Tribe and its Impact on Local Culture: Study of the Bajo Tribe in Bungin Village of South Konawe. Asian Culture and History, 9(2), 90-95. https://doi.org/10.5539/ach.v9n2p90.

Basri, Ali, Ode, La, Parimartha, Gde, I., Ardika, Wayan I., Mbete, Meko, Aron. (2011). Local Genius As Socio-Cultural Capital For Empowering The Bajo Ethnic People Residing at the Coastal Area of Bungin Permai Village, South East Sulawesi. E-Journal of Cultural Studies, 5(1), 1-9. Retrieved from https://ojs.unud.ac.id/index.php/ecs/article/view/3631

Indrawasih, Ratna dan Antariksa, IGP. (2003). Budaya Bajo: Pemanfaatan dan Pelestarian Lingkungan. Jurnal Masyarakat dan Budaya, 5(2), 57-79.

Ismail, Eafifi, Iziq, Ahmad, Hj, Sani, A., Ibrahim, Ismail. (2015). Influences of Regional Sama Bajau Coastal Dwellings: Social Perspectives through Identity Molding. International Journal of Culture and History, 1(2), 115-120. https://doi.org/10.1817/ijch.2015.1.2.022

Kazufumi dan Lapian. A. B. (1997, August, 26-28). Research on Bajau Communities: Maritime people in Southeast Asia. Makala dalam Widyakarya Nasional Antropologi dan Pembangunan di Hotel Indonesia Jakarta.

Saat, G. (2003). The Identity and Social Mobility of Sama Bajau. Sari, 21(2003), 3-11.

Saat, G., \& Mansur, MD., Kassim. (2016, April, 19-23). Issues in Diaspora of Sama Dilaut and its Consequences. Paper Presented at the International Conference on Bajau-Sama Diasporan and Maritime Southeast Asian Cultures. Inconbas-Masec.

Saidi, A. W. (2001). Bentuk Fungsi dan Makna Ruang pada Masyarakat Laut di Desa Tanjung Luar Lombok Timur (Tesis tidak dipublikasikan). Universitas Udayana, Bali, Denpasar.

Suryanegara, Ellen, Suprajaka, Nahib, Irmadi. (2015). Perubahan Sosial Pada Kehidupan Suku Bajo: Studi Kasus Di Kepulauan Wakatobi, Sulawesi Tenggara. Globe, 17(1), 67-78.

Taena, La., Sailan, Z., Nalefo, La., Basri, A., Ode, La., Laepe, A., Samsul, Hermina, Siti., Miliha, La., \&Kuasa, Wa. (2016). The Cultural Tradition of "Falia" in Preserving Porest by Munanese Ethnic. Journal of Sustainable Development, 9(2), 200-206. https://doi.org/10.5539/jsd.v9n5p200

Zakot, F. R. (2008). Orang Bajo Suku Pengembara Laut. Jakarta: Gramedia.

\section{Copyrights}

Copyright for this article is retained by the author(s), with first publication rights granted to the journal.

This is an open-access article distributed under the terms and conditions of the Creative Commons Attribution license (http://creativecommons.org/licenses/by/4.0/). 